\title{
Fostering Entrepreneurship Education among Women and Girls in South Africa: Destroying the
} Gendered and Encultured Patriachies

\author{
Tirivangasi H. M \\ University of Limpopo, Department of Sociology and Anthropology, South Africa \\ mathewtirivangasi@gmail.com
}

\begin{abstract}
Gender inequality has been in existence in as much as the humans themselves. The South African women and girls like many other societies around the world are also suffering from the lack of opportunities whilst men still receive favorable treatment. The government of South Africa engaged in the promotion of Small and Medium Enterprises (SMEs) as part of empowerment projects for the Black people since the attainment of democratic rule in 1994. Entrepreneurship continues to play an integral role in the South African economy as well as the economies of many developing countries around the world. The creation of new Small and Medium businesses activities contributes to economic growth, job creation, better livelihood of people involved and the communities which surround them. However, there has been a lack of women participation in entrepreneurship businesses in South Africa. Women continue to shy away from starting SMEs. Research reveals that an approximately 6, 2 percent of South African adult women were involved in SMEs in 2015. This is an appalling situation if South Africa is going to achieve Sustainable Development Goals (SDGs). The SDG, goal number five encourages States to 'Achieve gender equality and empower all women and girls'. The aim of this paper is to identify challenges faced by female entrepreneurs in South Africa, which makes their survival difficult within a patriarchal society. The empirical analysis is based largely on data from information available from sources such as journals, dissertations, thesis, books, conference reports, internet sources, and policy briefs relating to women and entrepreneurship.
\end{abstract}

Keywords: Entrepreneurship; Sustainable Development Goals; Small and Medium Enterprises; Gender inequality; Empowerment; Entrepreneurship Education

\section{Introduction}

South Africa, is facing many developmental challenges such as unemployment, poverty, inequality, increasing gap between the rich and the poor as well as poor governance.Small and Medium Enterpises (SMEs) play a critical role in the creation of employment, reducing high inequality, improving income distribution as well as reducing poverty rates(Ramukumba, 2014). This is in light of the disadvantages faced by women in the past, for example, during the apartheid era, it is imperative for woman to participate in the empowerment programmes.Women empowermentdrive through both political and economic emancipation has received greater attention over the past decade (Ramukumba, 2014). The increased number of female entrepreneurs will help in employment creation, eliminating poverty and the maintenance of sustainable development in South Africa. They are few women who are participating in entrepreneurship ventures in South Africa, with many showing low results on attitudes (Kelley, Brush, Green, Herrington and Ali, 2015). In South Africa, the SMEs sector has played an integral role towards fostering economic growth and development. This has encouraged the government to create policies aimed at helping the growth of SMES and to increase the budget towards SMEs development, improvement of entrepreneurship activity in the country and creating money-making initiatives for entrepreneurs (Ngek, 2014).

Small and Medium Enterprises contribute $61 \%$ towards job creation in both rural and urban areas. It provides stability, innovation and economic development in developing countries (Kongolo, 2010). Abor and Quartey (2010) notes that SMEs contributes an approximately between $51 \%$ and $57 \%$ of the gross domestic product and they account for about $91 \%$ of businesses operating in South Africa. The development of SMEs is quiet important since it contributes towards the elimination of poverty among the poor people living in rural areas. In most cases, it is the only source of income for the poor and low income households (Katua, 2014). Women are the most disadvantaged group in the society hence, their involvement play a critical role towards empowering them as well as the development of SMEs sector in the country. In many developing countries, women face challenges which are grossly embedded in socio-cultural, economic, political, legal and technological environments created by the partriachal society which they live in. Given this strife, this paper proposes entrepreneurship education as a solution to the lack of woman participation in the SMEs sector. 
This research can reveal that entrepreneurship education creates qualities which enable women to be selfsustainable individuals who have tolerance of risk, ambiguity and uncertainty; creativity, self-reliance and the ability to adapt. Entrepreneurship education increase societies' consciousness of self-employment as a path to alleviate unemployment. Further, it promotes the development of entrepreneurship attributes in women such as innovative thinking, commitment, risk taking, creation of social networking with right contacts and leadership qualities (Dzomonda, Tirivangasi and Masocha, 2016). This researcher believes that institutions of higher learning can play a critical role in fostering entrepreneurship education. This can be done through the creation of Centres of excellence aimed at developing entrepreneurial skill among woman and girls. Once equipped with the entrepreneurial skills, young girls and woman will be able to survive in the market place and in the process, help them to overcome poverty and South Africa will achieve Sustainable Development goals.

\section{Literature Review}

Woman and Entrepreneurship: There is still minimum research conducted on female entrepreneurship in South Africa and among the developing world (Mazonde and Carmichael, 2016; Brush and Cooper, 2012). Entrepreneur is a French word which dates to the 1700s, and it has been used to refer to someone who undertakes a venture (Herrington, Kew, Kew and Monitor, 2010). This field has been dominated by male entrepreneurs for in most societies, males were the most proactive people. Women entrepreneurs are women or a group of women, who initiate, organise and run a business enterprise (Manerkar, 2015). Women entrepreneurs engage and start their start their own business, taking all risk that comes with it (Chinomona and Maziriri, 2015). Scholars have revealed that women entrepreneurship comprises of a business initiative owned and skilfully managed by a woman and the she should own at least 51 percent of the shares; at least 51 percent of the employment generated in the enterprise should go to women (Chinomona and Maziriri, 2015; Arakeri, 2006).The participation of woman in entrepreneurship business remains low with one among eleven (8.9\%) women is being involved in entrepreneurship across the globe (Bajpai, 2014). However, the participation of women in SMEs adds value towards the emancipation of woman in the world. Moreover, we cannot ignore that, women are more than man in South Africa, Hence, their participation result in the economic growth, job creation and diversity of any economy around the world(Huarng, Mas-Tur and Yu, 2012; Reed, Storrud-Barnes and Jessup, 2012).

Types of female entrepreneurs: Women entrepreneurs fall into four categories namely, conventional female entrepreneurs, domestic female entrepreneurs, innovative female entrepreneurs and radical female entrepreneurs (Anderson and Woodcock, 1996). There is a constant mobility of these female entrepreneurs from on category to the other.

Conventional Female Entrepreneurs: These are type of entrepreneurs who are usually based at home. They engage in food, cleaning, cosmetic, knitting and grooming. In addition, women in this category act as both their own managers and they are also subordinate to the women's roles as spouses and mothers (Anderson and Woodcock, 1996; Shabbir and Di Gregorio, 1996). In most cases, women engaged in these businesses take their enterprises as a source of secondary income. They are less motivated and got no wish to expand their SMEs into flourishing business ventures.

Domestic Female Entrepreneurs: This group is more like the conventional female entrepreneurs; they start business due to influence of another person. They also want create surplus money from the money that is earned by their husbands already (Nxopo, 2014). This group of entrepreneurs do not start as serious sources of income but however may grow when the other source of income is depleted. These may include business such as hair dressing, interior design, selling on the informal markets.

Innovative Female Entrepreneurs: The female entrepreneurs who fall under this category are more serious and present a fundamental shift from the conventional or domestic female entrepreneurs. These are more educated on how to run SMEs or business in general, they are technically good. They display features of an entrepreneur for instance, they are concerned with self-advancement, they are not confined to the directive of their husbands (usually they are single and alone). Furthermore, these women are only satisfied with the 
success of their business, they compete with males for business opportunities and they devote mote more time in engaging with other business partners for future ventures (Nxopo, 2014).

Radical Female Entrepreneurs: This category has got proactive female entrepreneurs who are determined to achieve same objectives as many within the society, they believe in the empowerment of women within the society. These women are more independent and at one point of their life they have e 'glass-ceiling' which has been created by a patriarchal society in which they grew up in (Anderson and Woodcock, 1996). Furthermore, one noticeable feature among these women is lack of interest in profit making. However, they are determined in ending a male dominated society. Profit making comes as a secondary goal among this group of women. These women display the following characteristics: They are unmarried; tend to view their enterprises as an alternative to conventional family life; their backgrounds are largely middle-class and well educated; and their management style emphasises consultation and decision-making. Moreover, radical female entrepreneurs engage in businesses such as craft trading; retailing; education; small-scale manufacture; publishing and printing; and taxi services (Nxopo, 2014).

Theoretical framework of the study: This research adopts Social capital theory to explain how women can rely on social capital for them to forge successful enterprises. The social capital theory was developed through the works of the following scholars, (Bourdieu, 1986; Coleman, 1988; Coleman, 1990;Lin, 2002). Bourdieu (1986:248) notes that "Social capital is the aggregate of the actual or potential resources which are linked to possession of a durable network of more or less institutionalized relationships of mutual acquaintance and recognition". Individuals involved have social obligations and maintain networks within and among members of the group (Lin, 2002). Moreover, members of the group have gained resources and income from the partnerships that emerge during the networking. Coleman (1990) notes that when all members of the community contribute to the wellbeing of each other, eventually everyone will reap rewards; it does everyone good. Therefore, to sustain this collective assert, there is need to establish trust, norms, values and sanctions to govern the members of the group. Social capital refers to acquaintances among people, this include social networks and the norms of exchange and dependability that emerge from that (Putnam, 2002).

Towards a collaborative approach between women and male entrepreneurs: In a patriarchal society, social capital theory can be used in trying to find mechanism of making woman to survive in a male dominated society. There is need for women to gain skills and engage in successful business ventures. This can be achieved through forging partnerships of woman and man. The two cannot survive by neglecting the other, however, the creation of networking can create better environment for women. The social networking helps in the movement of information between different people which quicken the achievement of goals (Putnam, 2002). Networking is more important among female entrepreneurs than male entrepreneurs (Botha, Nieman and Van Vuuren, 2007). Research has shown that an approximately 870 million of the world's illiterates are female and the number is not expected to decrease in the next twenty years (Reynolds, Bygrave, Autio and Arenius, 2004). This researcher can assert that using networking women may gain a lot from men entrepreneurs. Moreover, due to lack of female role models, women cannot do away with male entrepreneurs completely but they can tap in from the knowledge posed by males and manage to operate their businesses effectively (Chiloane and Mayhew, 2010). Female entrepreneurs can create sustain long-standing relationships and networks, to effectively communicate ideas; to organise efficiently; to be fiscally conservative, to be aware of the needs of their environment, and to promote sensitivity to cultural differences (Jalbert, 2000). In addition, research has shown that most women consult more sources at the beginning of the business; this can only by creating better social networking between woman and man as well as among women themselves.

\section{Methodology}

Research design: This researcher adopted an exploratory research design for this secondary research. Burns and Grove (2003) define exploratory research as a research conducted to gain new insights, discover new ideas and to learn the truth about something. This is an appropriate research design for this research as the research seeks to find out a new solution to the challenges faced by women entrepreneurs in South Africa. 
Units of analysis: Cant, Gerber-Nel, Nel and Kotze (2005) notes that secondary research consist of data that already exists and can be gathered from internal and external sources. This consists of information available from other sources such as journals, dissertations, theses, books, conference reports, internet sources, and policy briefs relating women and entrepreneurship. Considering this, Babbie (2005) concurs that in social research they are virtually no limits to what or who or the units of analysis which can be studied. Secondary data documents with "women and entrepreneurship; challenges facing women entrepreneurs in South Africa" as the main theme were used as the units of analysis in this research.

Data collection: Data was collected from secondary sources. The documents used were chosen because they have certain characteristics or features for instance, information pertaining to women entrepreneurship, entrepreneurship education; and challenges facing women entrepreneurs in South Africa. Qualitative information was collected from the documents which contain relevant information.

Data analysis: Critical Discourse Analysis (CDA) was used to analyze data. The researcher followed three steps put forward by (Rohleder and Lyons, 2014), in conducting the discourse analysis. First stage, the researcher read through different texts or representations. The second stage is coding. In this stage the researcher selected materials for analysis using the research aim as the basis for selection. Then the research developed a coding frame, based on reading and rereading the data. Thirdly, the researcher highlighted and selects the relevant texts and file under the coding frame. The last stage is entitled analysis. At this stage the researcher read the coded data paying attention to the functional aspects of the discourse for instance looking whether discursive themes or interpretations repertoires can be identified.Rohleder and Lyons (2014) suggested that the research should be contextualized in the context of other discourse analysis studies. The analysis and the discussion should be combined followed by a separate conclusion and recommendations.

\section{Results and Discussion}

Challenges facing woman entrepreneurs in South Africa: This section identified and discussed the challenges faced by female entrepreneurs in South Africa, which makes their survival to be difficult within a patriarchal society.

Gender Bias or Gender Discrimination of Women Entrepreneurs: Sex discrimination or gender stereotyping is one of the challenges faced by women entrepreneurs in a patriarchal society that separate woman from their success. Discrimination involves the unequal treatment of various categories of people; people discriminate in the way they grant favours towards one person to the other based on sex, race and gender (Mandipaka, 2014). In most cases women are judged as inferior beings, they are regarded as unable to certain duties or job. South Africa, like other African nations are still facing the same problem of gender equity, a situation where women are regarded as competitive, independent and rational as man in spheres of business. The risks entrepreneurs face; women face woman still face male dominated field where they are regarded as supportive beings rather than equal partners (Wilson and Mitchell, 2004).The core difficulty lies with the unwillingness of banks to grant credit, lack of support, the negative socio-cultural attitudes and sex discrimination or gender bias(Valla, 2012).

Lack of Education and Training: The Global Entrepreneurship Monitor (GEM), report reveals that most of the women entrepreneurs interviewed in a study they conducted had a grade 12 school qualifications and other were having none (Maas and Herrington, 2006). The GEM report recognised that education presents a fundamental route to freedom for many women and people emerging from a disadvantaged background. The absence of education, it disadvantages many people from accessing useful. For instance, Small Enterprises Development Agency (SEDA) programmes are circulated through the Internet, newspapers and through the media. African continent is suffering from illiteracy and this urge women entrepreneur to undergo preentrepreneurial training in order plan an organized business venture successfully (Bajpai, 2014). Considering running business ventures can be a very risky and the challenges they face in a male dominated world, education becomes a necessity. Lack of education and training remains a challenge among woman running SMEs in South Africa (Oxford, Wood, Fischer, Herrington and Segal, 2003). Moreover, many women in developing countries remain illiterate and live in poor communities (Ascher, 2012). Woman always encounter difficulties in running their businesses due to lack skills and education (Jalbert, 2000). It can be 
noted that. There is a need for woman to be equipped with skill of how start up their businesses and to avoid being duped. The lack of pure business credentials limit woman in accessing funds to run business smoothly and at the end, they become reliant on males for support.

Work status: This is a serious challenge for emerging women entrepreneurs. There is lack of job opportunities assigned to women in South Africa and other developing countries. This hinders women from starting businesses since they do not have on the job experience. In most cases women turn to informal sector, starting unregistered business as means of survival rather than for business prowess. They see this outlet as unlicensed and it is therefore attractive to informal entrepreneurs (Morris, Pitt, Davis and Allen, 1992). The informal sector is offering economic activities that can be relied on to provide both adequate and secure alternatives to unemployment (Chiloane \& Mayhew, 2010). This research therefore reveals that women should be given employment opportunities, for them to venture more into formal entrepreneurship. It is unemployment, which encourages woman to start small businesses rather than big one due to lack of their own personal money. Men who are employed by big corporate find it easy to start their own businesses due to a big financial muscle which they have.

Cultural attitudes: In South Africa, woman comes against a background where they were viewed as legal minors, where they could not open bank accounts, sign property leases or conduct legal transactions without permission of their husbands (Linnegar and McGillivray, 1998). This is a regime which reign forced cultural attitudes which may hinder the progress of woman in South Africa. It increased the perception that woman is subordinate and they need to be taken care of, it instilled fear and inferiority whilst business itself requires assertiveness. This is still a case where working woman do not make personal decisions when it comes to their financial use and this restrict women from starting up their own businesses which may include risk and possibility of failure. Moreover, risk is even higher in societies where woman is living in a male dominated society where they face dangers from crime, domestic abuse and violence. The fear for women to start their own businesses is reinforced by religion, politics and lack of education. These are societal institutions which may hinder the progress of women within a society (Chiloane and Mayhew, 2010).

Lack of Skills: This happens when women entrepreneurs lack skills based training for instance they will exhibit deficiencies such administrative managerial, practical training, and relevant education. This constrains the growth of women entrepreneurship projects. Girls' and women's involvement in technical vocational education has been recorded a slow growth in African countries. In most instances when it comes to technical and vocational training women are limited to traditional occupations such as knitting, cooking, sowing, cookery and hair dressing (Spevacek, 2010). In most cases skills training programs are not developed in alignment with the demands from the labor market. As result of lacking skills woman often find themselves in low productive sectors in which most women operate for example doing business such as handicraft and horticulture. Further, women thrive in these sectors because they are no barriers placed by man in these sectors. Moreover, there is no potential for business growth due to the high number of people operating in those areas. In addition, women lack skills to grow their businesses so that they become globally competitive, this more attributed to poor product design, failure to understand the trade-related aspects of intellectual property rights, Lack of capacity serve large orders from new markets (Spevacek, 2010). These include lack of credit, technical skills, as well as understanding and complying with international specifications for their products (Spevacek, 2010).

Entrepreneurship and patriarchy: This is a major stumbling block on the way for woman empowerment and for most female entrepreneurs in general. This how woman is trained under patriarchy system, their role in the family remain un-negotiable. This something they are no longer forced to do or given reinforcement rather, it is something they do without hesitation. Leung (2011) presents the view that women can draw from the values and knowledge embedded in their normative gender roles when they embark on entrepreneurial endeavours. Studies have revealed that women struggle to make balance between home duties and work had a negative impact on the growth patterns among women owned firms. However, women operating in the formal SME environment see themselves as free from any cultural or family commitment which may impede their progress. In addition, research has revealed that women in sub-Saharan Africa contend with gender inequality, the result of patriarchal heritage. Moreover, society attaches little value to the work which they do at home and low paid work. However, this is what contributes to high poverty rates among women. That 
alone adds to less progress when we try to account why women are not involved in entrepreneurial business or SMEs development in South Africa (Spevacek, 2010).In addition to the domestic duties, the patriarchal society has made women to respect male domination. This has lead many women to appoint their husbands as director director as well. This is despite the knowledge of the husband about the business in question. This can lead to conflicting business decisions or interest, thus hindering the development of women entrepreneurship business among women.

Fostering Entrepreneurship Education and Training among young girls and Women Entrepreneurs: Education plays an integral role in the ensuring the success of women entrepreneurs in South Africa. They are attributes one can gain through the completion of acquiring education in entrepreneurship. These are qualities one is not born with but they are attributes one can acquire through being trained to become an entrepreneur. The attributes of a true entrepreneur are indicated in table 1 as defined by different scholars.

Table1: Attributes of entrepreneurs

(Gartner, 1990:21-26)

(Min, 1999:80)

(Bolton and Thompson, 2004:17) (Jonker, Saayman and De Klerk, 2009)

(Te Velde, 2004:123)

(Timmons and Spinelli, 2004)

(Botha, Nieman and Van Vuuren, 2007:166)
Innovation.

Organisation creation.

Creating value: transforming a business, creating a new business, growing a business and creating wealth.

Make profit.

Growth of business.

Uniqueness.

Owner-manager.

Recognising and taking advantage of opportunities.

Resourcefulness.

Creativity and innovation.

Visionary.

Independent thinker.

Hard worker.

Optimistic.

Risk taker.

Leader.

Ability to identify opportunities to utilise ideas.

Organisational skills.

Resourcefulness.

Achievement.

Self-edification.

Explorative.

Commitment.

Social intelligence: ability to recognise present and coming trends in society at a very early stage.

Imagination and empathy: ability to connect these trends with existing new combinations to change the conventional routines in the circular flow.

Establish a social network with the right people around the innovation.

A protected niche should be created to enhance the social network. Ability of the entrepreneur to up-scale the niche.

Commitment and determination.

Leadership.

Opportunity obsession.

Tolerance of risk, ambiguity and uncertainty.

Creativity, self-reliance and the ability to adapt. Motivation to excel.

Risk propensity.

Creativity and innovation. 
Opportunity identification.

Role model analysis (success factor).

Networking.

Leadership.

Motivation.

Social skills.

Start-up skills.

Sources: (Saayman, Douglas, \& De Klerk, 2008; Nxopo, 2014)

They are different scholars agree that entrepreneurship education plays a critical role in creating entrepreneurship awareness or tendencies (Alberti, Sciascia and Poli, 2004). This acquiring of skills such as entrepreneurial skills, knowledge and attitudes. This is what makes one entrepreneurship to be successful in setting up some effective businesses. The entrepreneurship attributes revealed in the table show that entrepreneurship education which is well developed creates female entrepreneurs who can create their own businesses and have the zeal to develop and succeed. It enables individuals to be able to identify hidden opportunities and motivates graduates to venture into business. It can be noted entrepreneurs are risk takers; hence, entrepreneurship education helps as motivator to still woman and girls towards taking similar risk as man. The avocation of the entrepreneurship attributes to all women will inspire a young generation of women to seek higher education as well as encourage them to take up business ventures which are often attributed to males (Stevenson and St-Onge, 2005).To make entrepreneurship education to be effective among young girls and women, it is imperative, to make this training compulsory (Daymard, 2015), from primary level up to matric level.

The pre-entrepreneurial training helps women to be able to plan and start successful business ventures (Bajpai, 2014). Moreover, to break the patriarchal stronghold on women, entrepreneurial education designed specifically for young girls and women must be designed to stir up the hidden ability of women to prosper in business. Various scholars reveal that entrepreneurship education have a positive effect on enterprise performance (Akanji, 2006; Chinomona and Maziriri, 2015; Cheston and Kuhn, 2002). Additionally, Bothaet al. (2006) recommends that women entrepreneurship education program should include the following areas of importance: monetary backing, administration assistance and training as well as networking, mentoring and counselling. In addition, to developing attributes of entrepreneurship in young girls and women, entrepreneurship education, it helps women understand the entrepreneurial process. This process involves four key stages namely, Identifying and evaluating the opportunity, developing a business plan, Determining the resource requirements and Starting and managing the enterprise. These are essential skills which need to be known by every entrepreneur before they start engaging in formal business entrepreneurship.

\section{Conclusion}

The challenges faced by young girls and women entrepreneurs are more closely linked to their background, which is filled with injustices brought about by the patriarchal society. In most communities' men were given advantages which made them dominant whereas women were made to be subordinates. This made women to be weak and lack the audacity to venture into business. Entrepreneurship education presents women with opportunity to be innovative, self-aware, earn confidence and skills to start out businesses without fear. Furthermore, instilling entrepreneurship education among woman from the grassroots level will help South Africa in achieving Sustainable Development Goal number 5 achieve gender equality and empower all women and girls'. This is a better way to empower young girls and women. Education itself liberates and empowers individuals to be able to survive in world where men are striving. This paper therefore concludes that with Entrepreneurship education, the future of young girls and women in South Africa and the developing world is bright.

\section{Recommendations:}

Creation of grassroots entrepreneurship organisations: There is need to set up entrepreneurship organisations from rural areas growth points and townships in urban areas in South Africa. These are organisations which must be run by women with minimum interference of man. The activities of these organisations should be to increase networking, technical assistance, capacity building and creation of 
associations which will serve as forums where young girls and women will meet and discuss ideas. This will increase formulation of partnerships as well as sharing ideas. Moreover, for young girls this will serve as a platform to identify role models. They are women who are already successful in running business; these will be invited to share their stories and motivations with young women. The existence of strong grassroots entrepreneurship organisations will help women to engage with the government and influence certain decisions made by the Minister representing women in the cabinet.

Entrepreneurship Centres: They are many universities in South Africa which can spear the development of entrepreneurship education. This can be done through the establishment of entrepreneurship centres. In other countries like America, the demand for entrepreneurship skills have so great to an extend that many universities, there, have created entrepreneurship centres (Katz, 2003). These can create the connection between the students and the prominent entrepreneurs in South Africa. This can be ensured through inviting or employing people who are in practice to come and train young girls and women at universities. In addition, the Centres can reach out to young girls and women by identifying individuals with a natural aptitude for creative and innovative business ideas and develop them. Entrepreneurship Centres can save a greater role of spreading the skills to less developed areas where young girls and women are located. The centre's work can be advertised in community radios, television and newspapers. Moreover, flyers and outreach teams can be used as recruitment exercise.

Integration of entrepreneurship within the education curriculum system: This can work hand in hand with the establishment of entrepreneurship centres. The process of integrating entrepreneurship into the curriculum system would start as a compulsory module for all matric students. The students with high potential can absorb into the centres at university. However, at university level entrepreneurship can be learned as module in all departments. This is a curriculum that can be tailor made to suit the needs of each department at all universities. The lectures conducting these modules can work in collaboration with the entrepreneurship centres.

Acknowledgements: I would like to give thanks to Obey Dzomonda for encouraging me to carry out this study. Further, I would like to thank Mr Shingirai Stanely Mugambiwa for reviewing my first draft.

\section{References}

Abor, J. \& Quartey, P. (2010). Issues in SME development in Ghana and South Africa. International Research Journal of Finance and Economics, 39(6), 215-228.

Akanji, O. (2006). Microfinance as a strategy for poverty reduction. Central Bank of Nigeria. Economic and Financial Review, 39(4), 78-102.

Alberti, F., Sciascia, S. \& Poli, A. (2004). Entrepreneurship education: notes on an ongoing debate. Proceedings of the 14th Annual IntEnt Conference, University of Napoli Federico II, 4. Italy.

Anderson, A.\& Woodcock, P. (1996). Effective entrepreneurship: A skills and activity-based approach. Cambridge: Blackwell publishers.

Arakeri, S. (2006). Women Entrepreneurship in India. Journal of Research in Arts \&Education, 1(3), 1-7.

Ascher, J. (2012). Female entrepreneurship-An appropriate response to gender discrimination. Journal of Entrepreneurship, Management and Innovation, 4, 97-114.

Babbie, E. (2005). The basics of social research. 3rd edition. Belmont, CA: Wardsworth Cengage Learning.

Bajpai, G. (2014). African Women Entrepreneur: Problems, Challenges and Future Opportunities. International Journal of Managerial Studies and Research, 2(5), 17-22.

Bajpai, G. (2014). African Women Entrepreneur: Problems, Challenges and Future Opportunities. International Journal of Manageral Studies and Research, 2(5), 17-22.

Bolton, B.\& Thompson, J. (2004). Entrepreneurs: Talent, temperament, technique. Oxford: Elsevier.

Bondarouk, T. \& Ruel , H. J. (2004). Retrieved August 18, 2017, from Discourse analysis: making complex methodology simple: http://doc.utwente.nl/47407/1/ECIS20041.pdf

Botha, M., Nieman, G. \& Van Vuuren, J. (2007). Measuring the effectiveness of the Women Entrepreneurship Programme on potential, start-up and established women entrepreneurs in South Africa. South African Journal of Economic and Management Sciences, 10(2), 163-18. 
Botha, M., Nieman, G. \& van Vuuren, J. (2006). Enhancing female entrepreneurship by enabling access to skills. The International Entrepreneurship and Management Journal, 2(4), 479-493.

Bourdieu, P. (1986).The forms of capital. In J. Richardson (Ed.), Handbook of Theory and Research for Sociology of Education (pp. 241-58). New York: Greenwood Press.

Brush, C. \& Cooper, S. Y. (2012). Female entrepreneurship and economic development: An international perspective. Entrepreneurship \& Regional Development, 24(1-2), 1-6.

Burns, N. \& Grove, S. K. (2003). The practice of nursing research: Conduct, critique and utilisation. Philadelphia: Saunders.

Cant, M., Gerber-Nel, C., Nel, D. \& Kotze , T. (2005). Marketing research. 2nd Edition. Cape Town: New Africa Books.

Cheston, S.\& Kuhn, L. (2002). Empowering women through microfinance. Draft, Opportunity International. New York: UNIFEM.

Chiloane, G. \& Mayhew, W. (2010). Difficulties encountered by black women entrepreneurs in accessing training from the Small Enterprise Development Agency in South Africa. Gender and Behaviour, 8(1), 2590-2602.

Chinomona, E. \& Maziriri, E. T. (2015). Women in action: Challenges facing women entrepreneurs in the Gauteng Province of South Africa. The International Business \& Economics Research Journal, 14(6), 835-841.

Coleman, J. (1990). Foundations of Social Theory. Cambridge: Harvard University Press.

Coleman, J. S. (1988). Social capital in the creation of human capital. The American Journal of Sociology, 94((Supplement)), S95-S120.

Daymard, A. (2015). Determinants of female entrepreneurship in India. Paris: OECD.

Dzomonda, O., Tirivangasi, H. M. \& Masocha, R. (2016). Entrepreneurship education as a panacea to redressing xenophobic attacks in South Africa: a focus on small and medium enterprises. Journal of Public Administration and Development Alternatives, 1(1.1), 75-90.

Gartner, W. B. (1990). What are we talking about when we talk about entrepreneurship? Journal of Business venturing, 5(1), 15-28.

Herrington, M., Kew, J., Kew, P. \& Monitor , G. (2010). Tracking entrepreneurship in South Africa: A GEM perspective. Cape Town: Citeseer.

Huarng, K., Mas-Tur, A. \& Yu, T. H. (2012). Factors affecting the success of women entrepreneurs. International Entrepreneurship and Management Journal, 8(4), 487-497.

Jalbert, S. (2000). Women entrepreneurs in the global economy. Retrieved February 24, 2017, from ciep.org: http://www.cipe.org/programs/women/pdf/jalbert.pdf

Jonker, E., Saayman, M. \& De Klerk, S. (2009). The role and attributes of entrepreneurs at South Africa' s largest arts festival. PASOS. Revista de Turismo y Patrimonio Cultural, 7(3), 381-392.

Katua, N. (2014). The role of SMEs in employment creation and economic growth in selected countries. International Journal of Education and Research, 2(12), 461-472.

Katz, J. (2003). The chronology and intellectual trajectory of American entrepreneurship education: 18761999. Journal of business venturing, 18(2), 283-300.

Kelley, D., Brush, C., Green, P., Herrington, P. \& Ali, A. (2015). Global Entrepreneurship Monitor. Retrieved February 24 , 2017, from Special Report Women's entrepreneurship: http://www.babson.edu/Academics/centers/blankcenter/globalresearch/gem/Docu ments/GEM\%202015\%20Womens\%20Report.pdf.

Kongolo, M. (2010). Job creation versus job shedding and the role of SMEs in economic development. African Journal of Business Management, 4(11), 2288-2298.

Leung, A. (2011). Motherhood and entrepreneurship: gender role identity as a resource. International Journal of Gender and Entrepreneurship, 3(3), 254-264.

Lin, N. (2002).Social capital: A theory of social structure and action. Cambridge: Cambridge University Press.

Linnegar, J. \& McGillivray, K. (1998). Women \& the Law in South Africa: Empowerment Through Enlightenment. Cape Town: Juta.

Maas, G. \& Herrington, M. (2006). Global entrepreneurship monitor: South African report. Graduate School of Business. Cape Town: University of Cape Town. .

Mandipaka, F. (2014). An Investigation of the challenges faced by women entrepreneurs in developing countries: A Case of King Williams' Town, South Africa. Mediterranean Journal of Social Sciences, 5(27), 1187-1196. 
Manerkar, G. (2015). Women Entrepreneurs in Goa: Issues and Challenges. Indian Streams Research Journal, 4(12), 1-8.

Mazonde, N. \& Carmichael, T. (2016). The influence of culture on female entrepreneurs in Zimbabwe. The Southern African Journal of Entrepreneurship and Small Business Management, 8(1), 10-17.

Min, S. J. (1999). Made not born. Entrepreneur of the Year Magazine, Fall, 80.

Morris, M., Pitt, L. F., Davis, D. L. \& Allen, J. A. (1992). Individualism-collectivism and corporate entrepreneurship: Cross-cultural comparisons. Frontiers of Entrepreneurship, 552-564.

Ngek, N. (2014). Determining high quality SMEs that significantly contribute to SME growth: regional evidence from South Africa. Problems and Perspectives in Management, 4, 253-264.

Nxopo, Z. (2014). The role of government in empowering female entrepreneurs in the Western Cape, South Africa (Doctoral dissertation). Cape Peninsula University of Technology, Cape Town.

Orford, J., Wood, E., Fischer, C., Herrington, M.\& Segal, N. (2003). Global Entrepreneurship Monitor: South African Executive Report. Cape Town: University of Cape Town.

Patton, M. Q. (1990). Qualitative research and evaluation methods. Newbury Park, CA: Sage.

Putnam, R. (2002). Bowling Alone: The Collapse and Revival of American Community. New York: Oxford University Press.

Ramukumba, T. (2014). Overcoming SMEs challenges through critical success factors: A case of SMEs in the Western Cape Province, South Africa. Economic and Business Review for Central and South-Eastern Europe, 16(1), 19-26.

Reed, R., Storrud-Barnes, S. \& Jessup, L. (2012). How open innovation affects the drivers of competitive advantage: Trading the benefits of IP creation and ownership for free invention. Management Decision, 50(1), 58-73.

Reynolds, P., Bygrave, W. D., Autio, E. \& Arenius, P. (2004). GEM 2003 global report. Wellesley: Babson.

Rohleder, P. \& Lyons, A. (2014). Qualitative research in clinical and health psychology. Basingstoke: Palgrave MacMillan.

Saayman, M., Douglas, M. \& De Klerk, S. (2008). Attributes of entrepreneurs at an arts festival. Southern African Journal of Entrepreneurs and Small Business Management, 2(1), 17-29.

Shabbir, A. \& Di Gregorio, S. (1996). An examination of the relationship between women's personal goals and structural factors influencing their decision to start a business: The case of Pakistan. Journal of Business Venturing, 11(6), 507-529.

Spevacek, A. (2010). Retrieved February 24, 2017, from Constraints to Female Entrepreneurship in subSaharan Africa: http://pdf.usaid.gov/pdf_docs/pnadm070.pdf.

Stevenson, L. \& St-Onge, A. (2005). Support for growth-oriented women entrepreneurs in Tanzania. Dar es Salaam: Programme on Boosting Employment through Small Enterprise Development, Job Creation and Enterprise Department, International Labour Office.

Te Velde, R. (2004). Schumpeter's theory of economic development revisited". Innovation, Entrepreneurship and Culture: The Interaction Between Technology, Progress and Economic Growth. Cheltenham: Edward Elgar.

Timmons, J. \& Spinelli, S. (2004). New venture strategies: Entrepreneurship for the 21st century. Burr Ridge, IL: Irwin-McGraw-Hill Publishers.

Valla, S. (2012). Retrieved February 10, 2017, from Barriers facing female entrepreneurs : a study in the Gauteng Province, South Africa: http://hdl.handle.net/10210/5591

Wilson, G. \& Mitchell, H. (2004). Home-based entrepreneurs. International Journal of Entrepreneurship and Small Business, 1(3-4), 249-254.

Woodilla, J. (1998). Workplace conversations: the text of organizing. In D. Grant, T. Keenoy, and C. Oswick (Eds.) Discourse and Organisation. London: Sage. 